\title{
GUT MICROBIOTA ASSESSMENT IN MOSCOW LONG-LIVERS USING NEXT GENERATION SEQUENCING
}

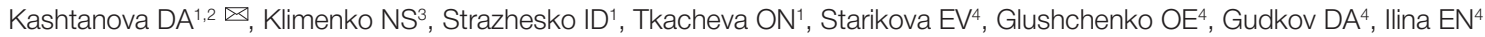

1 Pirogov Russian National Research Medical University, Moscow, Russia

${ }^{2}$ Center for Strategic Planning of FMBA, Moscow, Russia

${ }^{3}$ Institute of Gene Biology, Moscow, Russia

${ }^{4}$ Federal Research and Clinical Centre of Physical-Chemical Medicine, Moscow, Russia

Demographic aging poses a challenge to the medical community, pressing for research into the biological factors promoting longevity and its features. Below, we look at the gut microbiota as one of such factors. The aim of this non-longitudinal study was to profile the gut microbiota of centenarians and to compare it with that of relatively healthy, younger Moscow residents. The study recruited 20 people aged 97-100 years (mean age $98 \pm 1$ year); the control group consisted of 92 individuals aged $53 \pm 13$ years. For each stool sample, the variable V3-V4 regions of the microbial $16 \mathrm{~S}$ rRNA gene were sequenced. Primary analysis, read filtering and taxonomic identification were conducted in the QIIME 1.9 environment; reconstruction of metabolic pathways was aided by PICRUSt. Statistical analysis was performed by means of Python v. 3.2. A few differences were detected between the gut microbiota of centenarians and younger individuals: Bifidobacterium $(p=0.026)$ and Coprococcus eutactus $(p=0.026)$ were more abundant in centenarians, whereas Bacteroides $(p=0.003)$ and Prevotella $(p=0.002)$ were better represented in younger participants. The potential for butyric acid synthesis was higher in the group of centenarians $(p=0.048)$. Surprisingly, the gut microbiota of centenarians was more diverse and surprisingly beneficial for advanced age. Besides, the gut microbiota of centenarians might have more pronounced antiinflammatory potential due to its ability to better synthesize butyric acid.

Keywords: gut microbiota, longevity, butyric acid, aging, systemic low-grade inflammation

Funding: the study was supported by the Russian Foundation for Basic Research (Grant 19-34-80033).

Author contribution: Kashtanova DA — study design, participant recruitment, data interpretation, manuscript preparation; Klimenko NS — bioinformatic analysis, data interpretation, manuscript preparation; Strazhesko ID — study concept, manuscript revision; Tkacheva ON — study concept and design; Starikova EV — gut microbiota profiling, manuscript revision; Glushchenko OE, Gudkov DA — gut microbiota profiling; llina EN — final revision of the manuscript.

Compliance with ethical standards: the study was approved by the Ethics Committee of Pirogov Russian National Research Medical University (Protocol № 2 dated March 18, 2016). Informed consent was obtained from all study participants.

Correspondence should be addressed: Daria A. Kashtanova

1-ya Leonova, 16, Moscow, 129226; dr.kashtanova@gmail.com

Received: 01.07.2020 Accepted: 15.07.2020 Published online: 26.07.2020

DOI: $10.24075 / \mathrm{brsmu} .2020 .044$

\section{АНАЛИЗ МИКРОБИОТЫ ДОЛГОЖИТЕЛЕЙ МОСКВЫ С ИСПОЛЬЗОВАНИЕМ ВЫСОКОПРОИЗВОДИТЕЛЬНОГО СЕКВЕНИРОВАНИЯ}

\author{
Д. А. Каштанова ${ }^{1,2}$, Н. С. Клименко ${ }^{3}$, И. Д. Стражеско ${ }^{1}$, О. Н. Ткачева ${ }^{1}$, Е. В. Старикова ${ }^{4}$, О. Е. Глущенко ${ }^{4}$ Д. А. Гудков ${ }^{4}$, Е. Н. Ильина \\ Российский национальный исследовательский медицинский университет имени Н. И. Пирогова, Москва, Россия \\ 2 Центр стратегического планирования Федерального медико-биологического агентства России, Москва, Россия \\ ${ }^{3}$ Институт биологии гена, Москва, Россия \\ ${ }^{4}$ Федеральный научно-клинический центр физико-химической медицины Федерального медико-биологического агентства России, Москва, Россия
}

Старение населения ставит перед медицинским обществом задачу изучения здорового долголетия, предрасполагающих к нему биомаркеров и характерных особенностей. В настоящей работе рассмотрен один из таких факторов - микробиота кишечника. Целью исследования было изучить состав микробиоты кишечника долгожителей и провести сравнительный анализ с группой относительно здоровых более молодых лиц, проживающих на территории г. Москвы. В одномоментное исследование были включены 20 человек в возрасте 97-100 лет, средний возраст 98 土 1 год, в качестве группы сравнения была выбрана группа из 92 человек $53 \pm 13$ лет. Для участников исследования обеих групп проводили секвенирование V3-V4 вариабельных участков гена 16 S pPHK микробиоты кишечника. Для первичного анализа, фильтрации ридов и идентификации операционных таксономических единиц использовали QIIME 1.9, для реконструкции метаболических путей - алгоритм PICRUSt. Статистический анализ проводили с использованием языка Python v. 3.2. При межгрупповом сравнении были обнаружены значимые различия в микробиоте долгожителей и относительно здоровых лиц: в составе микробиоты первых были достоверно более представлены Bifidobacterium ( $p=0,026)$ и Coprococcus eutactus ( $p=0,026)$, в то время как у относительно здоровых лиц выявлено больше Bacteroides ( $p=0,003)$ и Prevotella $(p=0,002)$. Потенциал синтеза масляной кислоты был выше в группе долгожителей ( $p$ = 0,048). Состав микробиоты кишечника долгожителей оказался неожиданно благополучным, с большей представленностью полезных бактерий. Кроме того, можно говорить о возможном наличии у долгожителей более выраженного «противовоспалительного» потенциала микробиоты кишечника ввиду лучшей способности микробиоты синтезировать масляную кислоту.

Ключевые слова: микробиота кишечника, долголетие, масляная кислота, старение, системное вялотекущее воспаление

Финансирование: работа выполнена при поддержке гранта Российского фонда фундаментальных исследований 19-34-80033

Вклад авторов: Д. А. Каштанова - дизайн исследования, набор пациентов, интерпретация данных, написание статьи; Н. С. Клименко биоинформатический анализ, интерпретация данных, написание статьи; И. Д. Стражеско - концептуализация исследования, редактирование статьи; О. Н. Ткачева — концептуализация и дизайн исследования; Е. В. Старикова - анализ микробиоты кишечника, редактирование статьи; О. Е. Глущенко, Д. А. Гудков - анализ микробиоты кишечника; Е. Н. Ильина - финальное редактирование статьи.

Соблюдение этических стандартов: исследование одобрено этическим комитетом РНИМУ им. Н. И. Пирогова (протокол № 2 от 18 марта 2016 г.). Все участники подписали информированное добровольное согласие на участие в исследовании.

$\triangle$ Для корреспонденции: Дарья Андреевна Каштанова

ул. 1-я Леонова, д, 16, г. Москва, 129226; dr.kashtanova@gmail.com

Статья получена: 01.07.2020 Статья принята к печати: 15.07.2020 Опубликована онлайн: 26.07.2020

DOI: $10.24075 /$ vrgmu.2020.044 
The gut microbiota plays a crucial role in human health and disease. It is thought to be involved in the processes associated with aging. For example, it affects glucose metabolism [1], atherogenesis and cardiovascular health [2]. A link has been established between the gut microbiota and negative aging outcomes, such as frailty and other geriatric conditions [3]. It is hypothesized that the gut microbiota "ages" together with its host. As the host progresses into senescence, the diversity of microbial community inhabiting the gut declines, the abundance of opportunistic pathogens (Clostridium difficile, C. perfringens, and Escherichia coli) increases, whereas the number of beneficial microbes, including Lactobacillus, Bifidobacterium, and butyrate-producing bacteria essential in reducing inflammation, drops [4]. With age, endotoxins rise, whereas the levels of butyric acid decline [5]. Thus, the aging microbiota can drive low-grade inflammation underlying age-associated diseases.

Longevity is a unique model of aging. Long-lived individuals, who effectively realize their biological potential, have a delayed onset of age-related pathologies. Their gut microbiota is quite diverse and contains high levels of beneficial bacteria [6, 7]. In spite of advanced age, they manage to retain the pro- and antiinflammatory potential of their microbiota. This might be the antirisk factor for aging that the modern science is still searching for. Until recently, no research studies were conducted in Russia exploring the composition of the gut microbiota in long-lived individuals. The aim of this paper was to study the composition of the gut microbiota in such individuals and to compare it with that of younger Moscow residents without chronic conditions and of centenarians from other countries.

\section{METHODS}

Twenty participants were recruited for the study. The only inclusion criterion was age of $97-100$ years (mean age $98 \pm 1$ year). Exclusion criteria were as follows: antibacterial therapy, chemotherapy or probiotic therapy within 3 months before stool collection. All participants underwent a physical examination and a geriatric assessment; complete medical histories were taken. The Mini Nutritional Assessment (MNA) was used to identify malnourished individuals. The control group consisted of 92 individuals aged 25 to 76 years with no severe somatic pathology at the time of the examination. The demographics and clinical characteristics of the control group are described in [8].

For each stool sample, the variable V3-V4 regions of the microbial 16S rRNA gene were sequenced using a MiSeq Illumina sequencer (Illumina; USA) following the manufacturer's protocol. Libraries were prepared using a Nextera XT Index Kit (Illumina) and the 16S Metagenomic Sequencing Library Preparation protocol provided by the manufacturer. Metagenomic data analysis was carried out in the Knomics-Biota system [9]. Primary analysis, read filtering and taxonomic identification were conducted in the QIIME 1.9 environment [10]; reconstruction of metabolic pathways was aided by PICRUSt [11]. Statistical analysis was done with Python v. 3.2. In the group of long-lived individuals, the results were adjusted for multiple comparisons and sex using MaAsLin [12]; for intergroup analysis, adjustments were made for multiple comparisons, age and sex. All samples $(n=112)$ met the quality criteria for the number of mapped species $>70 \%$.

\section{RESULTS}

\section{Composition of gut microbiota in long-livers}

Symbiotic bacteria were the most abundant microorganisms in the gut microbiota of centenarians; many of them were butyrate-producing bacteria from the Christensenellaceae and Ruminococcaceae families and the Ruminococcus genus. All samples were close to the enterotype Ruminococcus [13]. They can be arbitrarily divided into clusters with low silhouette width. In terms of composition, all samples in this group were relatively similar to each other. The mean alpha-diversity value (the Shannon index) was $6.3 \pm 0.59$. The phylum distribution of bacteria looked interesting. In the group of centenarians, the Bacteroidetes phylum was lowly abundant, amounting to $7.8 \%$ of the gut microbiota, whereas Firmicutes made up $78.7 \%$ (Fig. 1). Clinical characteristics of the studied cohort of centenarians are provided in Table 1.

\section{Comparison of gut microbiota composition in centenarians and younger individuals}

The composition of the gut microbiota in relatively healthy younger participants was not out of the ordinary typically observed in healthy individuals. According to QIIME 1.9, Bacteroidetes made up an average of $20.23 \%$ of the gut microbiota, Firmicutes amounted to 73.4\% (Fig. 1). Differences in the abundance of Bacteroidetes were significant between the groups (adj. $p<0.002 ;$ MaAsLin).

In younger participants, the Shannon index was $7.56 \pm 0.49$, which was higher than in the group of centenarians; however, the difference was insignificant $(p=0.10)$.

The intergroup comparison at the genus and species levels produced a few remarkable findings. According to PCoA (Principal Coordinate Analysis), the samples collected from centenarians and healthy younger participants were different (Fig. 2).

A more thorough analysis allowed us to identify the differences in the gut microbiota of centenarians and other study participants. There were significantly more beneficial bacteria, including Bifidobacterium and Coprococcus, in the samples obtained from centenarians (Table 2).

The differences show on the MDS plot were confirmed by the MaAsLin analysis. The microbiota composition of healthy younger participants abounded with the bacteria representing 2 enterotypes: Bacteroides and Prevotella (Table 3).

\section{Reconstruction of metabolic pathways}

The analysis of metabolic pathways revealed that in long-lived participants, butyric acid synthesis through acetyl coenzyme A conversion was more prevalent than in younger individuals (adj. $p=0.048$; lda = 3.35); other butyrate synthesis pathways did not differ significantly between the groups (Fig. 3).

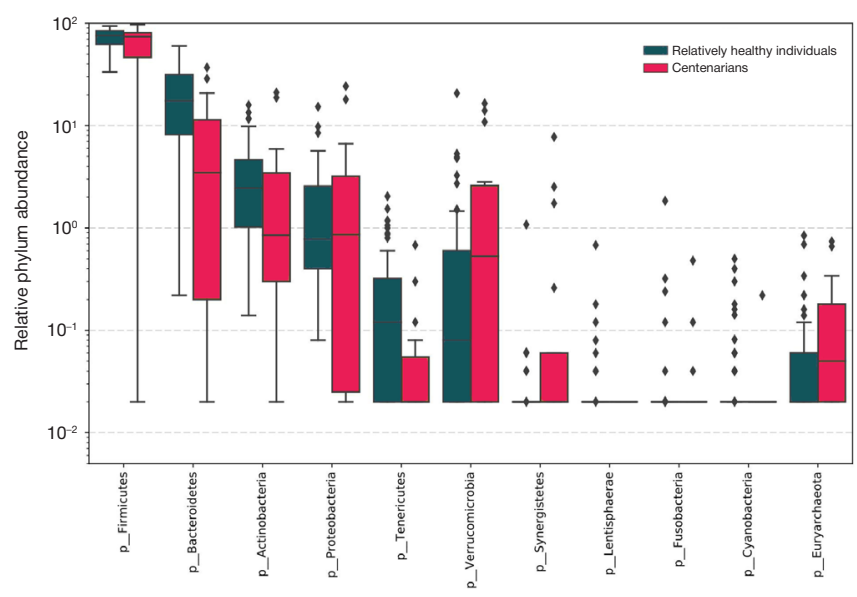

Fig. 1. Phylum distribution of gut microorganisms in the groups of centenarians and relatively healthy younger participants 
Table 1. Clinical characteristics of the centenarian group

\begin{tabular}{|c|c|c|}
\hline Factor & Median & IQR \\
\hline Body mass index, $\mathrm{kg} / \mathrm{m}^{2}$ & 25.10 & 5.66 \\
\hline "Age is no barrier" local scale (0-7 points) & 3.00 & 1.25 \\
\hline Systolic blood pressure, $\mathrm{mmHg}$ & 155.00 & 32.50 \\
\hline Diastolic blood pressure, $\mathrm{mmHg}$ & 78.00 & 9.00 \\
\hline Heart rate, beats/min & 69.00 & 9.00 \\
\hline Geriatric depression scale & 6.00 & 7.25 \\
\hline IADL & 16.00 & 9.25 \\
\hline MNA & 22.75 & 7.00 \\
\hline CIMT, mm & 1.31 & 0.25 \\
\hline Glycated hemoglobin, \% & 5.79 & 0.50 \\
\hline HSCRP, mg/L & 2.06 & 3.91 \\
\hline Triglycerides, $\mathrm{mmol} / \mathrm{L}$ & 1.04 & 0.34 \\
\hline High-density lipoproteins, mmol/L & 1.43 & 0.48 \\
\hline Low-density lipoproteins, mmol/L & 3.55 & 1.18 \\
\hline Hand grip strength, kg & 17.00 & 6.38 \\
\hline MOCA & 11.50 & 18.00 \\
\hline MMSE & 23.00 & 25.00 \\
\hline
\end{tabular}

Note: HSCRP — high-sensitivity C-reactive protein; CIMT — carotid intima-media thickness; IQR — interquartile range; IADL — Instrumental Activities of Daily Living; MMSE — Mini-Mental State Examination; MNA — Mini Nutritional Assessment; MOCA — Montreal Cognitive Assessment.

A possible association between a healthy diet and the microbiota composition/the potential for metabolite synthesis was analyzed in the group of centenarians. The analysis established an association with the prevalence of metabolic pathways. The MNA score was associated with the potential synthesis of a few types of vitamin B, especially B12. The higher was the score, the higher was the potential activity of some metabolic pathways, as demonstrated by MaAsLin (Table 4).

Thus, we have described a few characteristic features of the gut microbiota in centenarians and discovered that their microbiota was able to effectively synthesize butyrate through acetyl coenzyme A conversion.

\section{DISCUSSION}

The tremendous role of microorganisms inhabiting the human body is indisputable. Still, our knowledge of these inhabitants

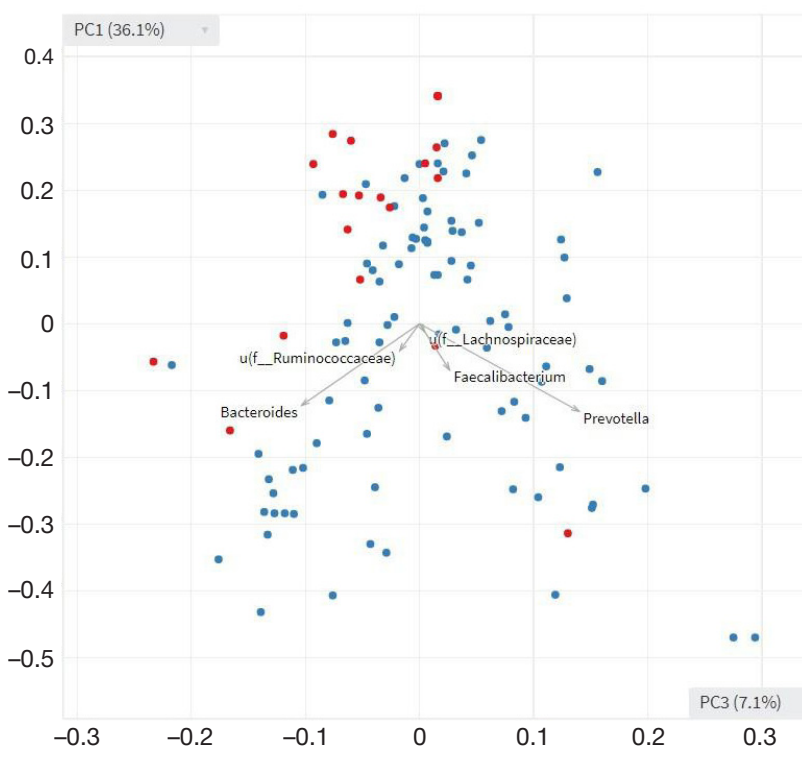

Fig. 2. A multidimensional scaling plot of gut microbiota samples obtained from centenarians (red dots) and relatively healthy individuals (blue dots). is very limited. The majority of currently known microbes were discovered not so long ago owing to the advances in next generation sequencing. The possible mechanisms underlying their effects on the human body remain understudied. Studies in humans are still scarce and mostly non-longitudinal. However, understanding the unique features of the gut microbiota in centenarians might be helpful in preventing conditions associated with its disturbances, including age-related diseases. The most important outcome of our study is the obtained profile of the gut microbiota of centenarians; its composition was found to be very beneficial for advanced age. Most studies looking into the "aging" gut microbiota demonstrate that the number of pathobionts increases with advancing age, while the number of beneficial bacteria declines [4]. This pattern, however, was not confirmed for healthily aging individuals.

Until recently, such studies were conducted abroad. One of them reported high levels of Bifidobacterium in a group of

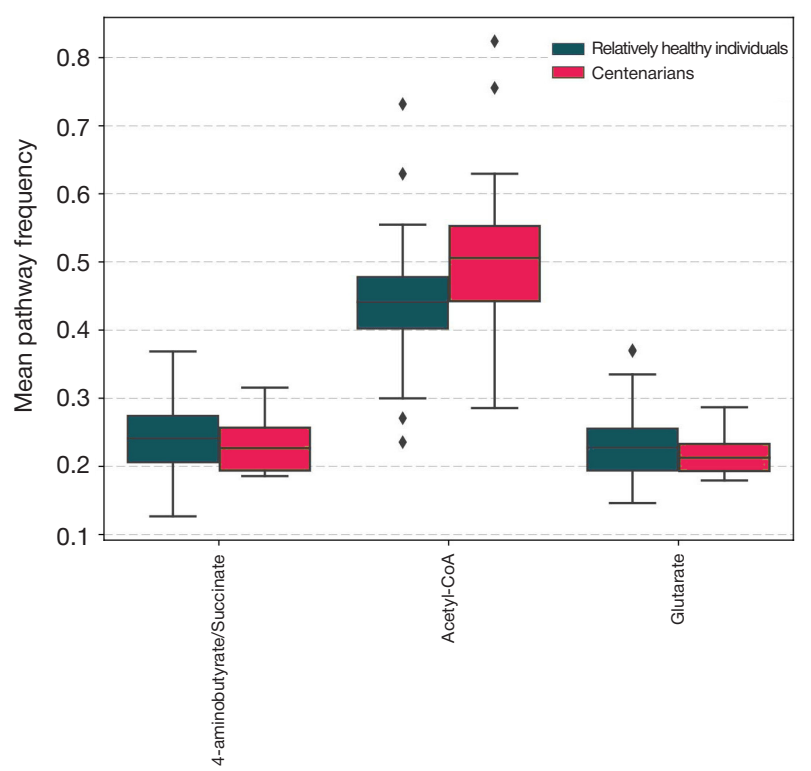

Fig. 3. Metabolic pathways for butyric acid synthesis in the groups (the mean prevalence of the pathways is plotted on the $Y$ axis) 
Table 2. Microorganisms found to be more abundant in the gut microbiota of centenarians

\begin{tabular}{|l|c|c|c|c|c|c|}
\hline & Relatively healthy M, \% & Relatively healthy IQR & Centenarians M, \% & Centenarians IQR & $p$ & adj. $p$ \\
\hline Bifidobacterium & 1.904 & 2.598 & 2.278 & 4.724 & 0.013 & 0.026 \\
\hline Bifidobacterium longum & 0.472 & 0.887 & 0.779 & 2.041 & 0.021 & 0.043 \\
\hline Coprococcus eutactus & 0.211 & 0.326 & 0.610 & 1.457 & 0.012 & 0.026 \\
\hline
\end{tabular}

Table 3. Microorganisms found to be more abundant in the gut microbiota of relatively healthy participants

\begin{tabular}{|l|c|c|c|c|c|c|}
\hline & Relatively healthy M, \% & Relatively healthy IQR & Centenarians M, \% & Centenarians IQR & $p$ & adj. $p$ \\
\hline Bacteroides & 9.917 & 10.418 & 3.999 & 6.011 & 0.001 & 0.003 \\
\hline Prevotella & 6.505 & 10.129 & 1.811 & 6.352 & 0.001 & 0.002 \\
\hline Dialister & 2.104 & 3.066 & 0.129 & 0.392 & $<0.001$ & 0.001 \\
\hline
\end{tabular}

Table 4. Associations between MNA scores and the prevalence of metabolic pathways for vitamin synthesis by the gut microbiota

\begin{tabular}{|l|l|l|l|}
\hline \multicolumn{1}{|c|}{ Vitamin synthesis pathway } & Coefficient & adj. $p$ & 0 \\
\hline $\mathrm{B}_{12}$ & 0.002048 & 0.009 & 0.001 \\
\hline $\mathrm{B}_{7}$ & 0.000681 & 0.043 & 0.015 \\
\hline $\mathrm{B}_{1}$ & 0.000588 & 0.048 & 0.024 \\
\hline
\end{tabular}

centenarians over 105 years of age, in comparison with middleaged individuals; this trend was observed in supercentenarians but not in their younger peers [6]. Interestingly, according to the same study Akkermansia and Christensenellaceae were also more abundant in centenarians. This sparked the hypothesis that maintaining a healthy microbiota might contribute to longevity.

In our study, pathogens and opportunistic pathogens were poorly represented in the gut microbiota; no difference in their abundance was observed between the group of long-lived individuals and younger participants. Moreover, Bacteroides and the Bacteroidetes phylum in general were poorly represented in the microbiota of centenarians. By contrast, a Japanese study [7] reports that the level of these bacteria increases in very old people.

In addition to having a beneficial composition, the gut microbiota of centenarians seems to affect the rate of aging; using the advanced tools for metabolism reconstruction, we were able to identify a few possible mechanisms underlying this effect. One interesting finding was discovery of high potential for butyrate synthesis in the gut microbiota of centenarians. Butyric acid is an anti-inflammatory agent [14, 15]; the ability of the gut microbiota to maintain its synthesis might slow down aging. In a recent experiment, butyric acid was administered to mice, leading to an increase in fibroblast growth factor
21 (the pleiotropic hormone); this elevation was found to correlate with the activation of AMPK and SIRT-1 and decreased activity of the mTOR signaling pathway [16], i.e. had a "rejuvenating" effect. We hope that further studies will be more conclusive and establish the cause and effect relationships. That said, we think that our finding reflects the main trends of healthy aging. High metabolic activity of the gut microbiota (vitamin synthesis) observed in centenarians who scored highly on the diet assessment scale should be interpreted with caution. Although vitamin transporters were detected in the colon [17], it is still unclear how critical is vitamin synthesis by the gut microbiota to maintaining sufficient levels of vitamins in blood.

\section{CONCLUSIONS}

Next generation sequencing gives us a chance to expand our knowledge of the microbial communities inhabiting the human body. This study shows that healthy old individuals over 97 years retain normal profiles of their gut microbiota. Maintaining healthy levels of symbiotic bacteria and high potential for butyrate synthesis might contribute to longevity by keeping the balance between pro- and anti-inflammatory potential of the gut microbiota.

\section{References}

1. Tilg $\mathrm{H}$, Moschen AR. Microbiota and diabetes: an evolving relationship. Gut. 2014; 63: 1513-21.

2. Tang WH, Kitai T, Hazen SL. Gut Microbiota in Cardiovascular Health and Disease. Circ Res. 2017; 120 (7): 1183-96.

3. Gemikonakli G, Mach J, Hilmer SN. Interactions between the aging gut microbiome and common geriatric giants: polypharmacy, frailty and dementia. J Gerontol A Biol Sci Med Sci. 2020; Feb 17: glaa047. DOI: 10.1093/gerona/glaa047. Epub ahead of print. PMID: 32064521.

4. Nagpal R, Mainali R, Ahmadi S, Wang S, Singh R, Kavanagh K, et al. Gut microbiome and aging: Physiological and mechanistic insights. Nutr Healthy Aging. 2018; 4 (4): 267-85.

5. Aleman FDD, Valenzano DR. Microbiome evolution during host aging. PLoS Pathog. 2019 Jul 25; 15 (7): e1007727.

6. Biagi E, Franceschi C, Rampelli S, Severgnini M, Ostan R, Turroni S, et al. Gut Microbiota and Extreme Longevity. Curr Biol. 2016; 26

(11): 1480-5.

7. Odamaki T, Kato K, Sugahara H, Hashikura N, Takahashi S, Xiao JZ, et al. Age-related changes in gut microbiota composition from newborn to centenarian: a cross-sectional study. BMC Microbiol. 2016; 16: 90.

8. Kashtanova DA, Tkacheva ON, Doudinskaya EN, Strazhesko ID, Kotovskaya YV, Popenko AS, et al. Gut Microbiota in Patients with Different Metabolic Statuses: Moscow Study. Microorganisms. 2018; 6 (4): 98.

9. Efimova D, Tyakht A, Popenko A, Vasilyev A, Altukhov I, Dovidchenko N, et al. Knomics-Biota - a system for exploratory analysis of human gut microbiota data. BioData Min. 2018; 11: 25.

10. Caporaso JG, Kuczynski J, Stombaugh J, Bittinger K, Bushman FD, Costello EK, et al. QIIME allows analysis of high-throughput community sequencing data. Nature methods. 2010; 7 (5): 335-6.

11. Langille MG, Zaneveld J, Caporaso JG, McDonald D, Knights D, 
Reyes JA, et al. Predictive functional profiling of microbial communities using $16 \mathrm{~S}$ rRNA marker gene sequences. Nature biotechnology. 2013; 31 (9): 814-21.

12. Mallick $H$, Ma S, Franzosa EA, Vatanen $T$, Morgan XC, Huttenhower $C$. Experimental design and quantitative analysis of microbial community multiomics. Genome Biol. 2017; 18 (1): 228.

13. Arumugam M, Raes J, Pelletier E, Le Paslier D, Yamada T, Mende $\mathrm{DR}$, et al. Enterotypes of the human gut microbiome. Nature. 2011; 473 (7346): 174-80.

14. Mishiro T, Kusunoki R, Otani A, Ansary MM, Tongu M, Harashima N, et al. Butyric acid attenuates intestinal inflammation in murine DSS- induced colitis model via milk fat globule-EGF factor 8. Lab Invest. 2013; 93 (7): 834-43.

15. Ohira H, Tsutsui W, Fujioka Y. Are Short Chain Fatty Acids in Gut Microbiota Defensive Players for Inflammation and Atherosclerosis? J Atheroscler Thromb. 2017; 24 (7): 660-72.

16. Kundu P, Lee HU, Garcia-Perez I, Tay EXY, Kim H, Faylon LE, et al. Neurogenesis and prolongevity signaling in young germ-free mice transplanted with the gut microbiota of old mice. Sci Transl Med. 2019; 11 (518): eaau4760.

17. Said HM. Intestinal absorption of water-soluble vitamins in health and disease. Biochem J. 2011; 437 (3): 357-72.

\section{Литература}

1. Tilg $H$, Moschen AR. Microbiota and diabetes: an evolving relationship. Gut. 2014; 63: 1513-21.

2. Tang WH, Kitai T, Hazen SL. Gut Microbiota in Cardiovascular Health and Disease. Circ Res. 2017; 120 (7): 1183-96.

3. Gemikonakli G, Mach J, Hilmer SN. Interactions between the aging gut microbiome and common geriatric giants: polypharmacy, frailty and dementia. J Gerontol A Biol Sci Med Sci. 2020; Feb 17: glaa047. DOI: 10.1093/gerona/glaa047. Epub ahead of print. PMID: 32064521

4. Nagpal R, Mainali R, Ahmadi S, Wang S, Singh R, Kavanagh K, et al. Gut microbiome and aging: Physiological and mechanistic insights. Nutr Healthy Aging. 2018; 4 (4): 267-85.

5. Aleman FDD, Valenzano DR. Microbiome evolution during host aging. PLoS Pathog. 2019 Jul 25; 15 (7): e1007727.

6. Biagi E, Franceschi C, Rampelli S, Severgnini M, Ostan R, Turroni S, et al. Gut Microbiota and Extreme Longevity. Curr Biol. 2016; 26 (11): 1480-5

7. Odamaki T, Kato K, Sugahara H, Hashikura N, Takahashi S, Xiao JZ, et al. Age-related changes in gut microbiota composition from newborn to centenarian: a cross-sectional study. BMC Microbiol. 2016; 16: 90

8. Kashtanova DA, Tkacheva ON, Doudinskaya EN, Strazhesko ID, Kotovskaya YV, Popenko AS, et al. Gut Microbiota in Patients with Different Metabolic Statuses: Moscow Study. Microorganisms. 2018; 6 (4): 98

9. Efimova D, Tyakht A, Popenko A, Vasilyev A, Altukhov I, Dovidchenko N, et al. Knomics-Biota - a system for exploratory

analysis of human gut microbiota data. BioData Min. 2018; 11: 25

10. Caporaso JG, Kuczynski J, Stombaugh J, Bittinger K, Bushman FD, Costello EK, et al. QIIME allows analysis of high-throughput community sequencing data. Nature methods. 2010; 7 (5): 335-6.

11. Langille MG, Zaneveld J, Caporaso JG, McDonald D, Knights D, Reyes JA, et al. Predictive functional profiling of microbial communities using $16 \mathrm{~S}$ rRNA marker gene sequences. Nature biotechnology. 2013; 31 (9): 814-21.

12. Mallick $\mathrm{H}$, Ma S, Franzosa EA, Vatanen $\mathrm{T}$, Morgan $\mathrm{XC}$, Huttenhower C. Experimental design and quantitative analysis of microbial community multiomics. Genome Biol. 2017; 18 (1): 228.

13. Arumugam M, Raes J, Pelletier E, Le Paslier D, Yamada T, Mende $\mathrm{DR}$, et al. Enterotypes of the human gut microbiome. Nature. 2011; 473 (7346): 174-80.

14. Mishiro T, Kusunoki R, Otani A, Ansary MM, Tongu M, Harashima N, et al. Butyric acid attenuates intestinal inflammation in murine DSSinduced colitis model via milk fat globule-EGF factor 8. Lab Invest. 2013; 93 (7): 834-43.

15. Ohira H, Tsutsui W, Fujioka Y. Are Short Chain Fatty Acids in Gut Microbiota Defensive Players for Inflammation and Atherosclerosis? J Atheroscler Thromb. 2017; 24 (7): 660-72.

16. Kundu P, Lee HU, Garcia-Perez I, Tay EXY, Kim H, Faylon LE, et al. Neurogenesis and prolongevity signaling in young germ-free mice transplanted with the gut microbiota of old mice. Sci Transl Med. 2019; 11 (518): eaau4760.

17. Said HM. Intestinal absorption of water-soluble vitamins in health and disease. Biochem J. 2011; 437 (3): 357-72. 